\title{
TINDAKAN PREVENTIF YANG HARUS DILAKUKAN DALAM MENUMBUHKAN PENDIDIKAN ANTIKORUPSI BAGI GENERASI MUDA
}

\author{
Edison Hatoguan Manurung \\ edisonmanurung2010@yahoo com \\ Mahasiswa S3 UTA45 Jakarta \\ Ina Heliany \\ Inaheliany6@gmail.com \\ Pasca Sarjana Universitas Mpu Tantular
}

\begin{abstract}
ABSTRAK
Ketika hari-hari kita di isi untuk menyaksikan kasus-kasus korupsi yang kian marak, meluas dan beragam, serta perilaku saling tidak percaya, saling menyalahkan, lepas tanggungjawab, mencari jalan pintas, arogan, inkonsisten, dan rupa-rupa perilaku tak pantas lainnya kian menyesakkan dada, kita sadar budaya antikorupsi kita menghilang.Kemanakah budaya antikorupsi kita? Di satu sisi Bangsa kita memiliki kelemahan perilaku yang diwariskan sebagai hasil penjajahan. Sejak lama kita sadari kelemahan ini. Mental menerabas, tidak menghargai waktu, meremehkan mutu, tidak percaya diri, dan banyak lagi.Sementara di sisi lain, dunia pendidikan yang diharapkan menjadi penguat budaya antikorupsi makin dirasakan tidak konsisten dalam menjalankan fungsinya. Proses pendidikan seperti mementingkan penguasaan pengetahuan semata ketimbang membiasakan perilaku baik. Sekalipun sekolah mengimplementasikan berbagai kegiatan sejenis, akan tetapi hal tersebut dilaksanakan seolah terpisah dari proses pembelajaran yang utuh. Kenyataan ini menunjukkan masih ada celah bagi pemberantasan korupsi melalui sektor pendidikan apabila kita bersungguh-sungguh bertekad memberantas korupsi tidak hanya di tingkat lembaga atau organisasi yang besar tetapi pada tingkat interaktif sesama manusia termasuk di dalam proses belajar pada generasi muda. Berdasarkan paparan diatas penulis tertarik untuk membahas mengenai upaya preventif apakah yang akan digunakan untuk menumbuhkan pendidikan anti korupsi bagi generasi muda ? Adapun upaya preventif yang akan digunakan untuk menumbuhkan pendidikan anti korupsi bagi generasi muda yakni Mengasuh Antikorupsi di Rumah dan Sekolah Antikorupsi di Sekolah.
\end{abstract}

Kata Kunci : Preventif; Antikorupsi dan Generasi Muda 


\title{
PREVENTIVE ACTIONS THAT MUST BE DONE IN GROWING ANTICORUPSY EDUCATION FOR YOUNG GENERATIONS
}

\author{
Edison Hatoguan Manurung \\ edisonmanurung2010@yahoocom \\ Doctoral student of UTA45 Jakarta \\ Ina Heliany \\ Inaheliany6@gmail.com \\ Post-graduate of Mpu Tantular University
}

\begin{abstract}
ABSTRAC
When our days are filled to witness corruption cases that are increasingly widespread, widespread and diverse, as well as behavior of mutual distrust, blaming each other, loose responsibility, looking for shortcuts, arrogant, inconsistent, and other forms of inappropriate behavior are increasingly stifling, we realize our anti-corruption culture is disappearing. Where is our anticorruption culture? On the one hand, our Nation has behavioral weaknesses inherited as a result of colonialism. We have long been aware of this weakness. Mental attacks, do not value time, underestimate quality, lack confidence, and more. While on the other hand, the world of education which is expected to be an amplifier of anti-corruption culture is increasingly felt to be inconsistent in carrying out its functions. The educational process is like emphasizing mastery of knowledge rather than getting used to good behavior. Even though the school implements a variety of similar activities, they are carried out as if they are separate from the whole learning process. This fact shows that there is still a gap for eradicating corruption through the education sector if we are truly committed to eradicating corruption not only at the level of large institutions or organizations but at the interactive level of fellow humans, including in the learning process of the younger generation. Based on the explanation above, the writer is interested in discussing what preventive measures will be used to foster anti-corruption education for the younger generation? The preventive measures that will be used to foster anti-corruption education for the young generation are Caring for AntiCorruption in Homes and Anti-Corruption Schools in Schools.
\end{abstract}

\section{Keywords: Preventive; Anti-Corruption and Young Generation}




\section{A. Pendahuluan}

Setiap hari kita menyaksikan berita tentang tindak pidana korupsi dan perilaku koruptif di mana-mana. Terjadi di hampir semua daerah di Tanah Air, di semua level, dan di semua segi kehidupan dengan beragam jenis, modus, dan kompleksitas. Perilaku koruptif telah merasuki semua elemen bangsa. Padahal kita semua tahu bahwa korupsi adalah perilaku yang tidak bermoral. Sebuah ironi. Muara dari persoalan korupsi adalah hilangnya nilainilai antikorupsi (jujur, peduli, mandiri, disiplin, tanggung- jawab, kerja keras, sederhana, berani, adil) dari dalam diri individu.Ketika hari-hari kita di isi untuk menyaksikan kasus-kasus korupsi yang kian marak, meluas dan beragam, serta perilaku saling tidak percaya, saling menyalahkan, lepas tanggungjawab, mencari jalan pintas, arogan, inkonsisten, dan rupa-rupa perilaku tak pantas lainnya kian menyesakkan dada, kita sadar budaya antikorupsi kita menghilang.Kemanakah budaya antikorupsi kita? Di satu sisi Bangsa kita memiliki kelemahan perilaku yang diwariskan sebagai hasil penjajahan. Sejak lama kita sadari kelemahan ini. Mental menerabas, tidak menghargai waktu, meremehkan mutu, tidak percaya diri, dan banyak lagi.Sementara di sisi lain, dunia pendidikan yang diharapkan menjadi penguat budaya antikorupsi makin dirasakan tidak konsisten dalam menjalankan fungsinya. Proses pendidikan seperti mementingkan penguasaan pengetahuan semata ketimbang membiasakan perilaku baik. Sekalipun sekolah mengimplementasikan berbagai kegiatan sejenis, akan tetapi hal tersebut dilaksanakan seolah terpisah dari proses pembelajaran yang utuh.

Selama ini indikator korupsi yang digunakan di tingkat internasional adalah Indeks Persepsi Korupsi (IPK) yang dikeluarkan tiap tahun oleh Tranparancy Internasional. Skala IPK yang digunakan adalah 1 hingga 10, dimana semakin besar nilai IPK berarti semakin tidak korup suatu negara demikian sebaliknya. Untuk tahun 2018 skor IPK Indonesia adalah 38. Indonesia sendiri menduduki rangking 89 negara terkorup dari 180 Negara. Hal menarik yang perlu dicermati adalah bahwa di dalam salah satu laporan 
badan resmi menunjukkan bahwa Departemen Pendidikan Nasional menempati peringkat ke-2 terkorup di tingkat pemerintahan setelah Departemen Agama pada peringkat pertama dan diikuti Departemen Kesehatan peringkat ke-3.

Korupsi adalah salah satu bentuk pelanggaran moral dan oleh sebab itu merupakan tanggung jawab moral dari pendidikan nasional untuk memberantasnya. Suatu tantangan bagi dunia pendidikan karena pendidikan mempunyai fungsi menanamkan, mengembangkan, dan melaksanakan nilai rasional, keberaturan, rajin (diligent), dan sikap produktif yang pada gilirannya mampu membawa manusia yang memiliki watak mulia, taqwa kepada Tuhan YME, dan mempunyai nilai-nilai kemanusiaan terhadap sesama. Sebagai proses pembudayaan dan membudaya, pendidikan diharapkan berperan dalam ikut memberantas korupsi yaitu dengan menyelenggarakan pendidikan antikorupsi.

Kenyataan ini menunjukkan masih ada celah bagi pemberantasan korupsi melalui sektor pendidikan apabila kita bersungguh-sungguh bertekad memberantas korupsi tidak hanya di tingkat lembaga atau organisasi yang besar tetapi pada tingkat interaktif sesama manusia termasuk di dalam proses belajar pada generasi muda.

\section{B. PERMASALAHAN}

Berdasarkan paparan diatas peneliti tertarik untuk membahas mengenai upaya preventif apakah yang akan digunakan untuk menumbuhkan pendidikan anti korupsi bagi generasi muda. Mengetahui upaya prefentif tentunya menjadi sangat penting dalam mendukung dalam memberikan jawaban-jawaban atas telaah praktik maupun teoritik.

\section{METODOLOGI}

Metode pendekatan yang digunakan dalam penelitian ini adalah metode pendekatan yuridis normatif, spesifikasi penelitian yang digunakan yaitu deskriptif. Pendekatan Normatif yaitu mempergunakan sumber-sumber data 
sekunder saja yaitu peraturan perundang-undangan, teori-teori hukum dan pendapat-pendapat para sarjana hukum terkemuka. ${ }^{1}$ Berkaitan dengan analisis data dilakukan secara kualitatif. Pendekatan Kualitatif digunakan karena merupakan proses analisis data tanpa menggunakan rumus dan angka-angka yang berasal dari informasi-informasi hasil studi kepustakaan yaitu data yang diambil dari instansi-instansi terkait maupun hasil pengamatan dalam penelitian yang dilakukan dengan masalah yang dibahas tersebut.

\section{TINJAUAN TEORITIK}

\section{Tindak Pidana Korupsi}

Tindak pidana korupsi merupakan salah satu bagian dari hukum pidana khusus di samping mempunyai spesifikasi tertentu yang berbeda dengan hukum pidana umum, seperti adanya penyimpangan hukum acara serta apabila ditinjau dari materi yang diatur. Karena itu, tindak pidana korupsi secara langsung maupun tidak langsung dimaksudkan menekan seminimal mungkin terjadinya kebocoran dan penyimpangan terhadap keuangan dan perekonomian negara. Dengan diantisipasi sedini dan semaksimal mungkin penyimpangan tersebut, diharapkan roda perekonomian dan pembangunan dapat dilaksanakan sebagaimana semestinya sehingga lambat laun akan membawa dampak adanya peningkatan pembangunan dan kesejahteraan masyarakan pada umumnya. ${ }^{2}$

Pemeriksaan terhadap tindak pidana korupsi dapat dilakukan melalui persidangan dan pemberian putusan juga dapat dilakukan tanpa kehadiran terdakwa sesuai dengan ketentuan Pasal 23 ayat 1 sampai dengan 4 UndangUndang Nomor 3 Tahun 1971 tentang Pemberantasan Tindak Pidana Korupsi dan Pasal 38 ayat 1, 2, 3, dan 4 Undang-Undang Nomor 31 Tahun 1999 tentang Pemberantasan Tindak Pidana Korupsi. Begitu pula bagi orang yang sudah meninggal sebelum adanya putusan, tidak bisa diubah lagi, yang diduga

${ }^{1}$ Ronny H. Soemitro, Metodologi Penelitian Hukum, (Semarang: Ghalia Indonesia, 1982), hlm. 9.

${ }^{2}$ Lilik Mulyadi, Tindak Pidana Korupsi di Indonesia (Normatif, Teoritis, Praktik dan Masalahnya), PT. Alumni, Bandung, 2007, hlm. 2. 
telah melakukan korupsi, hakim atas tuntutan penuntut umum, dapat menuntaskan perampasan barang-barang yang telah disita (Pasal 23 ayat 5 ). ${ }^{3}$

Penegakan hukum terhadap tindak pidana korupsi sangat berbeda dengan tindak pidana yang lain, diantaranya karena banyaknya lembaga yang berwenang untuk melakukan proses peradilan terhadap tindak pidana korupsi sebagaimana telah di sebutkan dalam alenia pertama. Kondisi demikian merupakan konsekuensi logis dari predikat yang di letakkan pada tindak pidana tersebut sebagai extra ordinary crime (kejahatan luar biasa). Sebagai tindak pidana yang dikategorikan sebagai extra ordinary crime tindak pidana korupsi mempunyai daya hancur yang luar biasa dan merusak terhadap sendi-sendi kehidupan suatu Negara dan bangsa. Dampak dari tindak pidana korupsi dapat dilihat dari terjadinya berbagai bencana alam dan kerusakan lingkungan seperti banjir, bahkan Nyoman Serikat Putra Jaya mengatakan bahwa akibat negatif dari adanya tindak pidana korupsi sangat merusak tatanan kehidupan bangsa, bahkan korupsi merupakan perampasan hak ekonomi dan hak sosial masyarakat Indonesia. $^{4}$

\section{Pendidikan anti korupsi}

Jika kita mengerucutkan pemaknaan pendidikan antikorupsi, yaitu pendidikan antikorupsi yang ditinjau dari sudut pandang pemahaman isu-isu moral yang lebih holistik dan berkarakter, akan muncul sebuah pemahaman baru tentang pendidikan antikorupsi sebagai satuan pembelajaran yang khas dan berpenciri. Sebagian kalangan berpendapat, bahwa pendidikan antikorupsi sebagai satuan pembelajaran hanya cocok bagi para siswa, tetapi bukan bagi kita, para guru, staf, karyawan, orang tua, pegawai, dll, yang secara usia dan pengalaman, katakanlah, tidak muda usia lagi dan sudah cukup berpengalaman. Satuan pembelajaran pada masa lalu bisa mengacu pada citra tertentu, kegiatan edukatif tertentu, atau fakta-fakta tentang pendidikan itu sendiri. Pendidikan ini

\footnotetext{
${ }^{3}$ Andi Hamzah, 2014, Pemberantasan korupsi melalui hukum pidana nasional dan internasional, Rajawali Pers, Jakarta. $\mathrm{h}$. 82

${ }^{4}$ Nyoman Sarekat Putra Jaya. 2008. Beberapa Pemikiran ke arah Pengembangan Hukum Pidana. Citra Aditya Bakti. Hlm. 69.
} 
biasanya mengacu pada pendidikan moral. Pendidikan moral inilah yang dapat mengantar dan membimbing mereka memasuki tahap kehidupan orang dewasa ${ }^{5}$.

Pendidikan anti korupsi tentunya sangat penting yang pertama adalah memutus mata rantai tindak pidana korupsi yang saat ini menjadi kebudayaan kita. Kedua adalah sebagai upaya menyadarkan keterlibatan generasi bangsa dalam berkontribusi di dalam penyelenggaraan pemerintahan. Hal tersebut tentunya sejalan dalam pandangan bahwa salah satu tujuan pendidikan antikorupsi sepatutnya adalah mengukuhkan nilai-nilai positif dalam pikiran dan persaan manusia. Manusia bisa kreatif, berwawasan luas, bahkan menjadi pemimpin yang baik apabila ia menimba nilai-nilai moral yang dituangkan oleh satuan pembelajaran ini ${ }^{6}$.

\section{E. PEMBAHASAN}

Korupsi di Indonesia bagaikan suatu "penyakit" yang sukar disembuhkan dan merupakan suatu fenomena yang kompleks. Untuk memberantas korupsi di Indonesia tidak cukup hanya dengan melakukan suatu tindakan represif, namun yang lebih mendasar lagi adalah melakukan tindakan preventif atau pencegahan. Salah satu upaya yang dapat dilakukan melalui tindakan preventif ini adalah dengan menumbuhkan kepedulian untuk melawan berbagai tindakan korupsi, dan sekaligus juga mendidik generasi muda dengan menanamkan nilai-nilai etika dan moral yang diperlukan dalam kehidupan bermasyarakat. Banyak hal yang dapat dilakukan, misalnya melalui kampanye publik, maupun melalui penanaman nilai-nilai moral dan etika yang dapat dimasukkan dalam kurikulum pada berbagai level terutama pada level pendidikan awal seperti SD, SMP dan SMA. Dengan upaya ini diharapkan mereka dapat tumbuh menjadi generasi yang "bersih" dan "anti korupsi" sekaligus menjadi contoh bagi generasi sesudahnya dan sebelumnya. Kesadaran dan kepedulian masyarakat perlu ditumbuhkan melalui berbagai cara, antara lain dengan mencanangkan "Gerakan Anti Korupsi", yang menandai komitmen berbagai elemen masyarakat dalam memberantas korupsi.

\footnotetext{
${ }^{5}$ Rosida Tiurma Manurung, Pendidikan Antikorupsi Sebagai Satuan Pembelajaran Berkarakter Dan Humanistik, Jurnal Sosioteknologi Edisi 27 Tahun 11, Desember 2012, hlm 237

${ }^{6} \mathrm{ibid}$
} 
Selama ini upaya menumbuhkan generasi yang bersih dan anti korupsi ini telah dilakukan melalui kerjasama antara Komisi Pemberantasan Korupsi (KPK) selaku lembaga pemerintah, Depdiknas dan sekolah sebagai pelaksanaan pasal 13 UU. No. 30 Tahun 2002 tentang Pemberantasan Tindak Pidana Korupsi, yaitu bahwa KPK menyelenggarakan program pendidikan antikorupsi bekerja sama dengan Depdiknas pada setiap jenjang pendidikan melalui sosialisasi, komunikasi, dan pendidikan. Tujuan pembelajaran pendidikan antikorupsi adalah: 1) pada saat terjun ke masyarakat siswa telah mendapat bekal yang cukup untuk dapat memahami etika di setiap level " social leaders" yang dijalaninya, 2) memahami secara komprehensif pentingnya etika baik di sektor publik maupun di sektor privat, 3) mengenali dan memahami dampak buruk korupsi terhadap kepercayaan masyarakat dan persaingan di dunia internasional, dan 4) memiliki keberanian dan kebijaksanaan untuk memberantas korupsi (Sjahruddin, 2006).

Saat ini, sadar atau tidak sadar, korupsi sudah merasuk kesegala sendi-sendi kehidupan bangsa kita. Perilaku dan tabiat ini sangat susah luar biasa ditanggulangi, perlu upaya luar biasa juga untuk membrangusnya dari bumi Indonesia. Salah satu langkah awal Indonesia untuk menanggulangi korupsi dengan membentuk Komisi Pembrantasan Korupsi (KPK) tahun 2002. Lembaga ini sudah memberikan harapan besar pada rakyat Indonesia untuk membrantas korupsi. Dari eksekutif, legislatif hingga yudikatif pernah merasakan 'baju khas' KPK itu, meskipun begitu, KPK tidak bisa bekerja sendiri, karena lembaga ini hanya terfokus pada korupsi puncak 'Gunung Es'. Untuk korupsi yang 'recehan' belum tersentuh.

Kini sudah 70 tahun Indonesia menghirup udara kebebasan, pertanyaan dibenak kita adalah mau sampai kapan kita akan menunggu negara Indonesia 'hancur' karena korupsi? Dimana letak kesalahan kita sampai Indonesia menempati negara terkorup nomor 89 dari 180 negara didunia? Pembrantasan korupsi yang dilakukan harus mengena semua, tidak hanya kelas 'kakap', tapi juga korupsi kelas 'teri'. Memang pekerjaan yang maha berat, tapi bukan tidak mungkin, bila upaya preventifnya kita temukan, maka 'bibit-bibit' korupsi akan tertanggulangi. Adapun upaya preventif yang akan digunakan untuk menumbuhkan pendidikan anti korupsi bagi generasi muda 


\section{Mengasuh Antikorupsi di Rumah}

Keluarga adalah tempat pertama seorang anak mengenyam pendidikan dan pondasi awal dalam pembentukan karakter anak. Ibarat sebuah rumah, bangunan yang pertama kali dibuat adalah pondasi rumah, pondasi yang kuat akan membuat rumah tidak mudah roboh meski diterjang angin kencang. Dirumah juga merupakan penanaman ideologi seseorang terbentuk pertama kalinya. Oleh karena itu, keluarga menjadi alat yang sangat efektif dan sangat fundamental dalam menumbuhkan budaya antikorupsi di Indonesia.

Bila melihat peran keluarga dalam membentuk karakter seseorang, maka semua anggota keluarga mempunyai andil yang sama. Peran ayah dan ibu sebagai otoritas tertinggi dalam rumah tangga menjadi sangat sentral, terutama peran ibu, karena sebagian waktu anak dihabiskan dirumah. Dari keluarga, penanaman nilai-nilai karakter termasuk didalamnya nilai kejujuran dan antikorupsi diteladani anak dari perilaku orang tuannya. Seperti cerita yang dituturkan oleh Ketua KPK non aktif, Abraham Samad, yang 'mencuri' kapur tulis berjumlah 5 batang, tapi ketika ibunya tahu, kapur yang 'hanya' berjumlah 5 batang itu harus dikembalikan karena untuk membelinya memakai uang negara. Bagi generasi muda sekarang mungkin hal itu sepele, tapi hal-hal sepele itulah yang membentuk karakter orang-orang besar didunia.

Kisah pendidikan antikorupsi yang dilakukan dirumah juga diceritakan oleh Mutia Hatta, anak sulung Bung Hatta. Beliau mengisahkan kalau mobil RI-2 hanya dipakai oleh ayahnya, termasuk ibunya pun tidak diperbolehkan menaiki mobil RI2, kecuali untuk acara kenegaraan. Selain itu sikap jujur dan menepati janji juga harus menjadi pondasi dalam pendidikan antikorupsi di rumah. Seperti kelanjutan kisah dari Mutia Hatta tadi, bahwa Bung Hatta mengajarkan kejujuran dan selalu menepati janjinya, karena Bung Hatta tidak pernah menjanjikan sesuatu kalau memang hal itu tidak dapat direalisasikan.

Pola asuh antikorupsi ini lebih lengkap bila diimbangi dengan sikap hidup sederhana meskipun serba ada. Kesederhanaan ini yang menjadi 'benteng' bila diserang dengan serangan-serangan uang, karena bila orang bersikap sederhana tentu akan berimbas pada rasa syukur dan cukup terhadap rezki yang sudah 
diberikan Tuhan yang Maha Esa. Tentu kita tidak meragukan besarnya gaji-gaji birokrat tingkat pusat, dari ratusan juta hingga milyaran tapi kenapa mereka masih saja mau menerima uang hasil korupsi? Jawabanya karena mereka tidak mempunyai rasa syukur dan rasa cukup terhadap gaji dan penghasilan yang sudah mereka dapatkan sebagai abdi negara.

Hal ini bertolak belakang dengan pendidikan yang dilakukan oleh orangorang besar didunia, misalkan kisah dari Soichiro Honda, pendiri dari Honda Motor Jepang, yang tidak mau memberikan warisan pada anak-anaknya, kecuali memberikan bekal kepada anak-anaknya untuk sanggup berusaha sendiri. Padahal Soichira mempunyai 43 perusahaan di 28 negara, dan yang lebih mencengankan lagi adalah, Soichiro lebih memilih untuk tinggal dirumah yang sederhana. Hal ini bisa dimaklumi, karena masa kecil Soichiro penuh dengan kerja keras dan kesederhanaan, ayahnya saja hanya seorang pandai bersi yang mengelola bengkel reperasi sepeda.

Sayangnya, di Indonesia masih banyak keluarga yang tidak menerapkan pola asuh antikorupsi dan kesederhanaan dalam rumahnya. Hal ini terlihat sangat jelas dari budaya korupsi berbagai 'versi', budaya korupsi versi lain ini justru diajarkan orang tua yang mungkin tanpa mereka sadari, mereka mendahului dengan seringnya mengajari berbohong terhadap anak-anaknya, misalkan, ketika ada tamu yang datang kerumah, si anak disuruh untuk mengatakan bahwa 'ayahnya tidak dirumah' padahal jelas-jelas ayahnya ada dan bersama anaknya dirumah. Contoh yang lain, misalkan anak sedang menangis, maka orang tuannya akan berbohong untuk menghentikan tangisannya, mereka berbohong ada 'orang gila' atau 'ada hantu'. Perilaku dan kebohongan-kebohongan kecil ini yang justru mengajarkan kepada anak bahwa bohong itu hal yang biasa dan diperbolehkan.

Setelah melihat contoh-contoh kejadian nyata diatas, kunci keberhasilan dari penanaman antikorupsi di rumah adalah dengan sifat ketauladanan, kesederhanaan dan kejujuran dari orang tuanya. Sifat-sifat ini sangat penting diimplementasikan dirumah, karena tidak semua orang tua 'mampu' melakukannya. Kebanyakan orang tua bila memberikan nasihat yang baik untuk anaknya mungkin semua orang tua bisa melakukan itu, tapi memberikan contoh 
yang nyata dari perilaku orang tua memang sangat berat tapi hal ini merupakan keharusan dan jurus yang ampuh untuk mendidik anak sejak dini mengenal kejujuran dan keteladanan sehingga secara tidak langsung mengajarkan anak prilaku antikorupsi.

\section{Sekolah Antikorupsi di Sekolah}

Sekolah merupakan rumah kedua bagi anak-anak, karena dalam kurun waktu 6-10 jam sehari mereka berada dilingkungan sekolah. Selain rumah, sekolah bisa menjadi tempat berseminya budaya antikorupsi, hal ini bisa dilakukan dengan pendidikan karakter melalui pembentukan soft sklills para peserta didik. Robert K Cooper, mengatakan bahwa apa yang mereka tinggalkan dibelakang dan acapkali mereka lupakan adalah aspek 'hati' atau kecerdasan emosi (EQ) dan aspek 'ilahi' kecerdasan spiritual (SQ). Keseimbangan antara aspek IQ, EQ bahkan SQ ini yang menyebabkan Finlandia menjadi negara percontohan dalam dunia pendidikan didunia.

Sistem pendidikan yang dilaksanakan di Finlandia tidak mengenal anak 'pintar' dan anak 'bodoh'. Mereka tidak pernah dipaksa untuk menguasai materi tertentu, tapi mengarahkan potensi dan bakat yang ada pada seorang anak tanpa ada pemaksaan apapun. Disana juga tidak pernah ada perangkingan, selain itu, setiap kelas harus terisi maksimal 16 peserta didik, sehingga pembelajaran lebih intensif dan maksimal. Dan yang terpenting di Finlandia adalah pendidikan disemua jenjang gratis, benar-benar gratis tanpa dipungut biaya apapun. Lalu bagaimana dengan dunia pendidikan kita?

Bila melihat fakta dunia pendidikan kita sekarang, rasanya masih jauh api dari panggangnya untuk menjadikan EQ dan SQ menjadi prioritas utama dalam pembentukan karakter peserta didik. Dari sistem pendidikan saja, Indonesia menempati salah satu peringkat terendah di dunia. Berdasarkan tabel liga global yang diterbitkan oleh firma pendidikan Pearson, sistem pendidikan Indonesia berada disalah satu posisi bawah bersama Meksiko dan Brasil. Tempat pertama dan kedua ditempati Finlandia dan Denmark. Itulah kenapa, negara Finlandia dan Denmark termasuk tiga besar negara terbersih dari korupsi didunia. 
Data diatas membuktikan bahwa dunia pendidikan kita masih tertinggal dan dalam keadaan yang stagnan. Bahkan Mendikbud, Anies Baswedan mengatakan "Peserta didik hidup di abad ke-21, guru-gurunya hidup dan memperoleh pendidikan dari abad ke-20, tapi ternyata, cara mengajar dan setting sekolah masih menggunakan pola abad ke-19”. Artinya, masih banyak guru-guru yang mengajar dengan cara konvensional dan hanya berorientasi pada nilai-nilai angka dan meninggalkan makna. Termasuk didalamnya budaya 'kolonial' yang masih ditemui, yaitu budaya korupsi.

Sudah menjadi rahasia umum bahwa dilingkungan sekolah pun korupsi masih tetap dengan mudah ditemui, dari penerimaan peserta didik baru sampai lulus, dari guru hingga peserta didik. Contoh kecil korupsi yang dilakukan oleh guru yaitu 'korupsi waktu' yang dilakukan ketika bel sudah masuk, tapi guru masuk kekelas 10-20 menit setelah bel. Belum lagi 'korupsi nilai', demi untuk memudahkan peserta didiknya lolos SNMPTN pihak sekolah rela 'merevisi' nilanilai rapotnya. Sedangkan korupsi yang dilakukan oleh peserta didik misalkan dengan 'korupsi mencontek'. Mereka rela melakukan segala sesuatu asalkan nilainya bagus, tanpa melihat proses memperoleh nilai itu didapat dari mencontek ataukah kejujuran. Dunia pendidikan kita (masih) tidak menghargai proses, sehingga para pelakunya pun lebih mementingkan sifat pragmatisme, kemudian yang baik dan yang kurang baik akan tercampur, dan pastinya yang baik lama-lama akan terseret kedalam kondisi yang kurang baik.

Sebetulnya pemerintah sudah berusaha untuk memasukan 'doktrin' antikorusi disekolah sejak tahun 2004 lewat Instruksi Presiden No 5/2004 tentang Percepatan Pemberantasan Korupsi, pada bagian Diktum ke-11 (Instruksi Khusus) poin ke 7 pemerintah sudah menginstruksikan kepada Menteri Pendidikan untuk mengadakan pendidikan yang berasaskan semangat dan sikap antikorupsi. Dari Kurikulum 2006 hingga 2013 yang sekarang diimplementasikan sebetulnya sudah mengarahkan peserta didik untuk mengarah kedalam pendidikan antikorupsi, tapi sebagus apapun kurikulum kalau guru yang menjadi 'ujung tombak' pendidikan tidak mau merubah mindset nya maka kurikulum yang sekarang akan percuma. Kita 
harus sedikit belajar dari negara-negara yang berhasil menurunkan angka korupsi dengan cara pendidikan.

Selain Finlandia, contoh 'negara' yang telah melaksanakan pendidikan antikorupsi di sekolah dan telah menunjukan hasil yang signifikan adalah Hongkong. Hongkong melaksanakannya semenjak tahun 1974 dan menunjukan hasil yang luar biasa. Jika tahun 1974 Hongkong adalah 'negara' yang sangat korup dan korupsi dideskripsikan dengan kalimat from the womb to tomb, maka saat ini Hongkong adalah salah satu kota besar di Asia dan menjadi kota terbersih ke-15 di dunia. Keberhasilan ini tidak terlepas dari efek simultan dan upaya pemberantasan korupsi dari segala segi kehidupan, termasuk pendidikan antikorupsi yang dilaksanakan di sekolah-sekolah secara formal dengan didukung oleh kualitas guru yang memadai. Indonesia sendiri pada tahun 1999 menempati posisi 5 besar negara terkorup, sedangkan tahun 2014 indonesia menempati posisi 107 dari 177 negara, artinya bangsa kita bisa berubah kearah yang lebih baik. Terlebih bagi seorang pendidik, tugas kita untuk melanjutkan perubahan itu, dengan cara membumikan budaya antikorupsi disekolah-sekolah.

Secara umum, masyarakat kita belum sepenuhnya melakukan pola asuh antikorupsi di rumah dan sekolah, tercermin dari perilaku para orang tua dirumah dan guru disekolah. Perbaikan terhadap situasi ini harus kontinyu dan sinergis antara semua stakeholder, seperti pemerintah, lembaga-lembaga yang terkait serta masyarakat sekitar. Orang tua selaku peletak pondasi karakter anak harus menanamkan pola asuh antikorupsi dan pihak sekolah yang merupakan rumah kedua harus mengimplementasikan kurikulum-kurikulum yang sudah memberikan ruang untuk mengajarkan antikorupsi dengan benar dan tepat sasaran.

Mengacu pada tujuan dan target pendidikan antikorupsi diatas, maka pembelajaran antikorupsi hendaklah didesain secara moderat dan tidak indoktrinatif. Pembelajaran yang dialami peserta didik merupakan pembelajaran yang memberi makna bahwa mereka merupakan pihak atau warga negara yang turut serta memikirkan masa depan bangsa dan negara ini kedepan, terutama dalam upaya memberantas korupsi sampai keakarnya dari bumi Indonesia. Hanya dengan menempatkan peserta didik pada posisi inilah pendidikan antikorupsi akan 
mempunyai makna penting bagi mereka, jika tidak mereka akan cenderung beranggapan bahwa pendidikan antikorupsi hanyalah urusan politik semata, sebab mereka bukanlah orang-orang yang melakukan korupsi dan belum tentu juga akan berbuat korup dimasa depannya.

Dunia pendidikan kita dilapangan kadang hanya mengejar angka-angka tanpa melihat nilai-nilai karakternya. Kita sepakat, bahwa orang Indonesia tidak kalah pintar dengan bangsa lainnya, tapi yang membedakan bangsa lain punya karakter yang kuat sehingga negara mereka maju. Tapi pendidikan karakter kita justru menjadi nomor dua, yang terpenting nilai angka-angka bagus diatas kertas tanpa melihat prosesnya. Selain itu, hal yang paling berpengaruh terhadap keberhasilan pendidikan antikorupsi dirumah dan sekolah adalah sikap ketauladanan. Sebagai orang tua dirumah, tentunya kita harus terbiasa dengan sikap ketauladanan. Anak-anak tidak akan membutuhkan nasihat yang terlalu banyak, mereka akan menilai sendiri apakah nasihat orang tuannya itu. Justru anak-anak akan lebih 'kena' dengan ketauladanan dibandingkan dengan nasihat tanpa tindakan. Kita biasakan untuk menanyakan kepada anak 'nak, tidak apa-apa mendapat nilai 6, asalakan didapat dari kejujuran' kita tinggalkan kebiasaan kita yang selalu menuntut kepada anak harus mendapatkan nilai bagus, tanpa melihat proses usaha mereka mendapatkannya. Kita harus belajar dari orang-orang besar dalam mendidik anak-anak mereka, atau belajar dari negara-negara besar dalam membenahi sistem pendidikan dan pemerintahannya, tapi harus tetap di 'bumikan' ke Indonesia. Seperti ucapan Tan Malaka, 'Belajarlah dari Barat, tetapi jangan peniru Barat. Melainkan jadilah murid dari Timur yang cerdas'.

Akhirnya, setelah bangsa Indonesia jatuh bangun dan bertranformasi sejak Orde Lama, Orde Baru hingga reformasi, sekarang keputusan ada dipundak kita untuk membersihkan bangsa Indonesia dari korupsi yang merajalela, dimulai dari diri kita, keluarga sampai sekolah demi menegakan pondasi yang kokoh dalam membangun dan memperjuangkan tegaknya Indonesia bersih dari korupsi. Kita harus tetap optimis untuk menuju pada perubahan ditengah kondisi yang bobrok, kita harus belajar tidak hanya memberikan nasihat terhadap anak tapi juga memberikan ketauladanan dan perilaku yang nyata dan yang terakhir, kita harus 
terus mendukung KPK dalam perjuangannya menghadapi 'tikus-tikus berdasi', sehingga kita menjadi masyarakat yang dengan setulus jiwa raga memvisualisasikan nilai-nilai antikorupsi dirumah dan sekolah. Mari kita menjadi pahlawan versi modern (terlebih saya mengingatkan pada diri saya sendiri) dan terus mengobarkan semangat antikorupsi dari diri kita, dari rumah hingga sekolah dan sekarang juga. Dan kita juga harus mendukung KPK dari 'serangan-serangan yang sehalus sutra' untuk melemahkan KPK!

\section{F. PENUTUP}

Dari pembahasan diatas maka dapat disimpulkan bahwa upaya preventif yang dapat dilakukan untuk menumbuhkan pendidikan antikorupsi dapat dilakukan dengan dua cara yaitu Mengasuh Antikorupsi di Rumah dan Sekolah Antikorupsi di Sekolah. Diharapkan dengan melakukan dua upaya preventif diatas maka generasi muda kita tidak tertarik untuk melakukan budaya korupsi, dan dengan pasti serta keyakinan mengatakan bahwa katakan TIDAK untuk KORUPSI.

\section{DAFTAR PUSTAKA}

Agustian, Ary Ginanjar. 2007. Rahasia Sukses Membangun Kecerdasan Emosi dan Spiritual ESQ. Jakarta: Arga Publising.

Andi Hamzah, 2014, Pemberantasan korupsi melalui hukum pidana nasional dan internasional, Rajawali Pers, Jakarta

Harahap, Krisna. 2009. "Pemberantasan Korupsi Masa reformasi (Suatu Tinjauan Historis)". Historia: Journal of Historical Studies X. Hlm 130 -140.

KPK. 2006. Modul I - Pendidikan Anti Korpsi Bagi Pelajar.

Lilik Mulyadi, Tindak Pidana Korupsi di Indonesia (Normatif, Teoritis, Praktik dan Masalahnya), PT. Alumni, Bandung, 2007

Mahfud MD, Prof. Dr. Moh. 2006. Bunga Rampai Politik dan Hukum. Semarang: Rumah Indonesia.

Miles. Matthew B. dan A. Michael Huberman. 1992. Analisis data Kualitatif. Terjemahan Tjetjep Rohendi Rohidi. Jakarta: UI-Press.

Montessori, Maria. 2012. Pendidikan Antikorupsi Sebagai Pendidikan Karakter di Sekolah. Jurnal Ilmiah Politik Kenegaraan. Vol 11, No 1. Hlm 293-301.

Nyoman Sarekat Putra Jaya. 2008. Beberapa Pemikiran ke arah Pengembangan Hukum Pidana. Citra Aditya Bakti

Paton, Michael Quinn. 1989. Qualitative Evaluation Methods. London and New Delhi:Sage Publication, Inc.

Rasul, Sjahrussin. 206. Dalam Makalah KPK dalam Seminar Nasional tanggal 13 September 2006. 
Ronny H. Soemitro, Metodologi Penelitian Hukum, (Semarang: Ghalia Indonesia, 1982)

Rosida Tiurma Manurung, Pendidikan Antikorupsi Sebagai Satuan Pembelajaran Berkarakter Dan Humanistik, Jurnal Sosioteknologi Edisi 27 Tahun 11, Desember 2012

Saefudin, Arif dan Suyoko, Dwi. 2015. Pemuda dan Tawaran Solusi Problematika Bangsa. Wonosobo: Gema Media.

Saputra, Dwi. dan Qonik Hajah Marfuah- Supraptiningsih. 2006. Hukuman Percobaan Kasus Korupsi Eksaminasi Publik Perkara No. 340 / Pid.B/2005/PN Smg. Semarang: KP2KKN. Umar, Musni. dan Syukri Ilyas. 2004. Korupsi Musuh Bersama. Jakarta: Lembaga Pencegah Korupsi.

Susetyo, Benny. 2004. Hancurnya Etika Politik. Jakarta: Buku Kompas.

Syam, M.Noor.dkk. 1987. Pengantar Dasar- Dasar Kependidikan. Surabaya: Usaha Nasional.

Taufiq Siddiq. Indeks Persepsi Korupsi Indonesia 2018 Naik Jadi 38 Poin retrifed from : https://nasional.tempo.co/read/1170330/indeks-persepsi-korupsiindonesia-2018-naik-jadi-38-poin. Tanggal 27 Mret 2020.

Tilaar, H.A.R. 2004. Multikulturalisme Tantangan - Tantangan Global Masa Depan Dalam Tranformasi Pendidikan Nasional. Jakarta: PT.Grasindo

Undang - Undang Nomor 30 Tahun 2002 tentang Komisi Pemberantasan Tindak Pidana

Wiyono, S.H., R. 2005. Pembahasan Undang- Undang Pemberantasan Tindak Pidana Korupsi. Jakarta: Sinar Grafika.

Yin, Robert K. 1997. Studi Kasus Desain dan Metode. Terjemahan M. Djauzi Mudzakir. Jakarta: Raja Grafindo Persada 